\title{
Sigér Fruzsina
}

\section{Troméniából Paradoxiába}

\author{
Musto István: Utazás Paradoxiába. \\ Egy úgynevezett szakértö feljegyzéseiböl, Könyvmühely, 2012
}

„Musto” fogalom a Debreceni Egyetem Világgazdaságtan és Nemzetközi Kapcsolatok Tanszékének oktatói és hallgatói között. Előadásai minden tankönyv és egyetemi jegyzet felett állnak, az akadémia és a gyakorlati tapasztalat ideális keverékét tárja a hallgatói elé. A szigorúan vett tananyag történelembe, földrajzba, filozófiába ágyazódik, és persze mindenre van konkrét példa, közvetlen tapasztalat a tarsolyában. Musto ráadásul úgy tud „mikor legutóbb Bogotában jártam” kezdetü történeteket (ha úgy tetszik, esettanulmányokat) mesélni, hogy közben nem henceg, nem nagyképü, de még csak nem is álszerény.

Bátran állíthatjuk, hogy az Utazás Paradoxiába rég várt kötet a szerzőt ismerők körében. Egyrészt a tantermekből és tanszéki vacsorákról ismert történetek papírra kívánkoztak ${ }^{1}$, másrészt sejthető volt, hogy tovább is van (mondja még!).

A kötet nem sorolható egyetlen tipikus műfaji kategóriába sem, „nem életrajz, nem novelláskötet, nem tudományos értekezés, nem fantázia, nem ezotéria, nem emlékirat és nem is irodalom", ahogy szerző maga is előrebocsátja. Az ember unitas multiplex, írja, azaz nem fér bele egydimenziós müfajok kategóriáiba. A kötet a felsorolt müfajok mindegyikét tartalmazza egy-egy írás erejéig, s ez a müfaji és stílusbeli sokszínűség, melybe egyaránt belefér a mély filozófiai elmélkedés és a könnyed anekdotázás, de még az aktuálpolitizálás is, pontosan leképezi a szerző sokszínü személyiségét és széles látókörét. „A mondanivalók mesterséges szétválasztása és besorolása úgynevezett müfajokba valójában az átélt valóságok megerőszakolása” - írja (7. o.) 79 év élettapasztalattal a háta mögött, s neki el is hisszük. Arról nem szól a szerző, hogy kit tart célközönségének. A témák és müfajok sokszínüsége, és a közvetlen, könnyed stílus okán bizton állíthatjuk, hogy „közönségkönyvről” van szó, azaz nem csak a szűkreszabott tudományos vagy szakértői világ olvasóinak íródott, hanem „laikusok” számára is érdekes és élvezetes olvasmányról van szó.

Musto a hiteles emberek közzé tartozik. Hiteles, mert világlátott, térben és időben, azaz földrajzilag és történelmileg egyaránt. Az írásokból egyértelműen kiderül, hogy rendkívül olvasott, ugyanakkor nem csak az íróasztal mögül beszél, hanem tapasztalatból is. Halmozottan nem igaz a szerzőre az egyik írás H. Menckentől kölcsönzött mottója: „Akik

Sigér Fruzsina a Debreceni Egyetem Közgazdaság-és Gazdaságtudományi Karán egyetemi adjunktus.

E-mail: fruzsina.siger@econ.unideb.hu

${ }^{1}$ Ha nem is gyüjteményes kötetben, de rendszeresen jelentek meg a szerző írásai a Mozgó Világ címü folyóiratban. 
valamit tudnak, azt teszik is. Akik nem tudják tenni, azok oktatják. Akik nem tudják sem tenni, sem oktatni, azok igazgatják" (57. o.).

Mustónak bőven van témája, hiszen mozgalmas élete során több emberre való kaland történt meg vele. Ha valakiére, az ő életútjára igaz a mondás, miszerint a valóság felülmúlja a képzeletet. A kötet 35 írást tartalmaz, 79 év „élménylomtárából” válogatva, az első írásban felvázolt müfaji szabadságnak, a szerző szavaival élve „müfajtalankodásnak” megfelelően. A 35 írásban van életrajz, tudomány, fantázia, ezotéria ${ }^{2}$, és irodalom is, különösebb logikai rendszer nélkül, s „,ez szándékosan van így, mert ezek az élmények, elgondolások, képzetek, értékelések egyszerre vannak jelen”. S bár a szerző irtózik a kategóriákba préseléstől, a kötet írásai mégiscsak csoportokba rendezhetők, melyeket a kötet bemutatása során a recenzens számba vesz.

Amint a kötet alcíme (Egy úgynevezett szakértő feljegyzéseiből) is sugallja, a szerző fejlesztéspolitika és fejlődés-gazdaságtan terén szerzett nemzetközi (élet)tapasztalatai jelentik a könyv vezérfonalát. Az alcím kissé provokatív, hiszen a szerző foglalkozását tekintve valóban szakértő, nemcsak „úgynevezett”. Ez a szarkasztikus-cinikus-ironikus, sőt, olykor groteszk „szakértőséghez” való hozzáállás végigkíséri a kötet történeteit, mégsem uralja a kiábrándultság vagy az értelmetlenség hangulata a könyvet, bár kétségtelen, hogy ennek a két érzésnek a szele is meg-megcsapja az olvasót. A szakértő (esetünkben legalábbis) a világ jobbításán dolgozik, és amikor azt tapasztalja, hogy a világ javíthatatlan, okkal keseredik el. „Aki a tudást, vagy a szakértelmet keresi, vagy akár a világ folyását akarná alakítani, annak nagyobb valószínűsége van a csalódásra, a tehetetlenségre, a kétségbeesésre, mint annak, aki nem keres semmit és alakítani sem akar" - summázza a szerző (36. o.), s kár is lenne vitatkozni vele. Aztán persze megpróbálja azt is meg(szak) érteni, hogy miért van ez így : „a professzionális szakértő számára (...) a kudarc nem okoz csalódást, mert ösztönző erővel hat arra, hogy az illető felkutassa a sikertelenség okát, ami újabb feladatokat eredményez, (...) és a megbízások véghetetlen folyamatát biztosíthatja. (...) A csalódás, a hiábavalóság érzete azokban merül fel, akik csakugyan az hitték, hogy meg tudják változtatni ezt a világot, amely olyan, amilyen” (41. o.). Végül az is kiderül, hogy miért van szükség cinizmusra: „aki nem a professzionális szakértők cinizmusával közeledik az ún. harmadik világ problémáihoz, az nem ússza meg mélységes csalódások nélkül” (42. o.). „Lehet, hogy a cinizmus semlegesíti az értékeket és tompítja az érzelmeket, de egy olyan védőfalat állít fel a csalódásokkal szemben, amely mögött az úgynevezett szakértelem a tévutak vesztőiben is éber, józan, felvilágosult és működőképes marad (47. o.).

A szerző szakértőként szerzett konkrét tapasztalatai és élményei tehát számos írás témájául szolgálnak, hol komoly, hol könnyed formában. Az olvasó bepillantást nyer abba, hogy lesz valakiből egy véletlen folytán szakértő, és milyen hajmeresztő, olykor mesébe illő kalandokba keveredik utazásai során. A kötetben található egy-egy írás érdekes adalékul szolgál egy-egy tudományos cikk vagy szakértői jelentés mellé. Az Âtkozott szabadság címü történet például bepillantást enged a Journal of Common Market Studies-ban megjelent, a Kanári-szigetek EK-tagságát vizsgáló cikk (Musto 1981) kulisszatitkaiba. A Hová lett a segély? címü történetből pedig kiderül, hogy milyen bonyolult is szakvéleményt írni, mennyi nem várt helyzet és félreértés adódik a tanulmányút során, amit aztán kellő diplomáciával és tudományossággal kell szakértői anyaggá formálni (lásd: Musto 1985).

Egyik-másik írásban arra derül fény, hogy a szerző az élet értelmét, az „igazságot” is

2 Itt most eredeti jelentésében: csak beavatottaknak érthetö. 
kutatja. A kötetet keretbe foglaló két tudományos-fantasztikus történetben az író izgalmas, istenkísértésbe hajló istenkeresésébe is bepillantást enged az olvasónak.

A szakértő is ember, gyerekkorral, családdal, iskolákkal, szerelemmel, utazásokkal. A történetek során kirajzolódik a magánember, amint kisgyerek egy nagy családban, majd kisdiák Debrecenben, aztán ahogy a háborúval új fejezet kezdődik, Németország és Spanyolország ad otthont a fiatal egyetemistának és szerelmes pályakezdőnek. Unitas multiplex szerzőhöz méltóan a szerelmi szál sem hiányzik a könyvből, meghatóan őszinte és legalább annyira kalandos „love story”-t találunk a kötetben: „Világjárásom közepette néha megkérdezték, volt-e magánéletem. Volt. Szenvedélyes és csodálatos, végül tragikus (118. o.)."

Bár nem tudományos kötetről van szó, a szerző bepillantást enged életének és gondolkodásának tudományos berkeibe is néhány írás erejéig. Igazi társadalomtudós rajzolódik ki az írásművekből, aki a társadalomtudományok mindegyikében jártas, ha úgy tetszik, társadalomtudományi polihisztor, akit a természettudományok területén sem lehet „eladni”. Kvantofrénia című írásában például a közgazdaságtan nagy kérdésére keresi a választ: formalizáljunk vagy sem (bővebben: Musto 2010).

A történetek közül talán a legeredetibbek a fantáziák, azaz a valóságtól (nem is olyan nagyon) elrugaszkodott darabok, amelyek nem kötődnek a szakértői hivatáshoz, annál inkább a szerző kreatív elméjéhez. Megismerhetjük a néger diktátor, Thrasybule ${ }^{3}$ esetét a magyar forradalommal, amely elsőre igazi fikciónak tünik, aztán kiderül, hogy inkább tanmese. A szerző „korai alkotásaiba” is bepillantást nyerünk, mikor megnyílik a kapu Troméniába, a gyerek Musto által kitalált országba. Troménia mára „egy kisebb ládára való kézirat térképekkel, feljegyzésekkel, arcképekkel, vázlatokkal” (248. o.). Az évek múlásával Troménia történetének szövete nem szövődött tovább, illetve talán más dimenzióba helyezte át a székhelyét, és Paradoxia lett belőle. Bár a szerző azt írja, nem hiszi, hogy valakit is érdekelne egy Troméniáról szóló regény, a kötet végére tartogatott izgalmas írást olvasva az olvasó minden vágya, hogy belekukkanthasson abba a ládába, és még több történetet olvasson Mustótól, legyen az fikció vagy valóság, szóljon Troméniáról vagy Paradoxiáról.

\section{Hivatkozások}

Musto, Stefan A. (1981): The Canary Islands and the EC - Options for Integration. Journal of Common Market Studies, Vol. 20. No. 2. pp. 115-138.

Musto, Stefan A. (1985): Evaluation of the EDF financed regional projects in the Caribbean ACP states: Synthesis. Német Fejlesztéspolitikai Intézet, Berlin

Musto István (2010): Kvantofrénia? Néhány megjegyzés a társadalom és gazdaságtudományok formalizálásának feltételeiről. Competitio, IX. évfolyam, 2. szám, 5-18.o.

${ }^{3}$ A történelmi Thrasybulus athéni hadvezér a peloponnészoszi háborúban, a demokrácia elkötelezett híve. 